Ilmu Dakwah: Academic Journal for Homiletic Studies Vol 10 No 2 Juli-Desember 2016 p-ISSN 1693-0843 http://journal.uinsgd.ac.id/index.php/idajhs DOI: http://dx.doi.org/10.15575/jid.v10i1.334

\title{
Pola Komunikasi Kelompok Komunitas Muballig Kota Makasar
}

\author{
Syamsuri* \\ IAIN Datokrama Palu \\ *syamsuri@gmail.com
}

\begin{abstract}
This study will examine expressly group communication patterns. The purpose of this study was to obtain an overview of the communications phenomenon muballig in Makassar city, how the management of the impression and appearance Muballig in Makassar, and how well integrated in the group communication patterns in the Community Muballig in Makassar. This study uses a qualitative approach to the Phenomenology of theoretical studies subjectivist communication group. As used road mapper structuration theory and dramaturgy. The results showed that, the communication patterns muballig community groups in Makassar contains values of religious life, through symbols which are exchanged at every layer of the social strata.Muballig reality of life in the city of Makassar displaying religious symbols that indicate the presence of solidity and solidarity groups. Communication patterns in community groups muballig in Makassar is an integrated pattern. Integrated pattern based on the ideological polarization refers to the mass organizations, political parties and institutions of propaganda in Makassar. Pattern-based integrated inspiration shown by muballig to emulate, imitate and idolize popular muballig muballig-nan charismatic, both in terms of appearance (aesthetics) and rhetoric. While the pattern of an integrated based on their identity, namely the muballig in Makassar characterized in shades radical, moderate and liberal.
\end{abstract}

Keyword : Communication patterns, Islamic Preacher, Impression Management

\section{ABSTRAK}

Penelitian ini dengan tegas akan mengkaji pola komunikasi kelompok. Adapun tujuan penelitian ini adalah untuk memperoleh gambaran mengenai fenomena komunikasi muballig di kota makasar, bagaimana pengelolaan kesan dan penampilan Muballig di Kota Makassar, dan bagaimana pula pola terintegrasi dalam komunikasi kelompok pada Komunitas Muballig di Kota Makassar. Penelitian ini menggunakan pendekatan kualitatif dengan Fenomenologi studi teoritis kelompok komunikasi subyektif. Sebagai jalan mapper teori strukturasi digunakan dan dramaturgi. Hasil penelitian menunjukekan bahwa, pola komunikasi muballig kelompok masyarakat di Makassar mengandung nilai-nilai kehidupan beragama, melalui simbol-simbol yang dipertukarkan pada setiap lapisan strata.Muballig realitas sosial kebidupan di kota Makassar menampilkan simbol-simbol keagamaan yang menunjukekan adanya soliditas dan kelompok-kelompok solidaritas. Komunikasi pola dalam kelompok masyarakat muballig di Makassar adalah pola terpadu. pola terpadu berdasarkan pada polarisasi ideologi mengacu pada organisasi massa, partai politik dan lembaga propaganda di Makassar.

Kata Kunci : Pola Komunikasi, Muballig, Pengelolaan Kesan

Naskah diterima: 6 Sept 2016, direview 1 Nov 2016, disetujui: 14 Nov 2016

Ilmu Dakwah: Academic Journal for Homiletic Studies, Vol 10 No 2 | Juli - Des 2016 


\section{PENDAHULUAN}

Profesi di bidang dakwah mengundang banyak orang untuk menggelutinya, karena di samping sebagai panggilan keyakinan keagamaan berupa tugas suci, kegiatan dakwah juga dapat menghasilkan keuntungan finansial. Sebagaimana profesi lainnya, profesi di bidang dakwah menimbulkan persaingan internal karena masing-masing anggota ingin menampilkan eksistensinya, dalam rangka memperoleh kesempatan yang lebih besar di banding dengan anggota lainnya. Persaingan itu menimbulkan keanekaragaman model dan strategi pemasaran dakwah untuk memikat perhatian khalayak, karena dengan keterterimaan dakwah tersebut, peluang untuk tampil semakin besar.

Berbagai cara yang ditempuh oleh para pelaku dakwah yang juga disebut muballig untuk memperkuat profesionalisme. Mulai dari penguasaan keilmuan agama Islam hingga penampilan muballig ketika berdakwah. Penyediaan struktur, infrastruktur dan suprasruktur dakwah terus dilakukan untuk menyukseskan profesi muballig. Struktur itu berupa organisasi dakwah yang berfungsi sebagai "event organizer" sehingga tertata sistem dakwah yang mengefisienkan penampilan muballig. Infrastruktur dakwah berupa saranasarana mobilitas yang dapat mengantarkan muballig tepat waktu sampai di tempat dakwah, fasilitas pengeras suara (sound system) yang mengefektifkan suara muballig sampai kepada pendengar dan infrastruktur dakwah lainnya seperti media komunikasi yang kini sedang berkembang lalu dapat mengantarkan muballig menjadi populer. Sedangkan suprastruktur dakwah adalah terciptanya ideologi dakwah yang mengantarkan muballig memiliki identitas mazhab sehingga lebih mudah dikenali referensi dakwahnya.

Perwujudan suprastruktur dakwah diantaranya adalah terbentuknya kelompok-kelompok atau korps sebagai jaringan informasi, sarana meningkatkan pengetahuan dakwah serta tempat diskusi membicarakan tantangan dakwah kontemporer. Para muballig di Kota Makassar tersebar di berbagai kelompok. Ada kelompok muballig di bawah naungan organisasi massa berskala nasional seperti Muhammadiyah, Nahdlatul Ulama (NU), Dewan Dakwah Islam Indonesia (DDII), Tarekat Naqsyabandiyah, dan Hizbut Tahrir Indonesia (HTI). Ada yang di bawah organisasi massa berskala regional seperti As'adiyah, Darud Da'wah wal Irsyad (DDI), Ikatan Masjid Mushallah Muttahidah (IMMIM), Wahdah Islamiyah dan Hidayatullah.

Selain organisasi massa, ada juga kelompok muballig di bawah naungan organisasi sosial politik seperti Partai Keadilan Sejahtera (PKS), Partai Persatuan Pembangunan (PPP), Partai Amanat Nasional (PAN), Partai Kebangkitan Bangsa (PKB), Majelis Dakwah Islamiyah di Partai Golkar, dan Baitul Muslimin Indonesia di Partai Demokrasi Indonesia Perjuangan (PDIP). Keterlibatan partai-partai politik dalam kegiatan dakwah menunjukkan bahwa

200 Ilmu Dakwah: Academic Journal for Homiletic Studies, Vol. 10 No.2 | Juli-Des 2016 
betapa emosional akidah dan ibadah umat Islam memiliki potensi massa yang dapat membesarkan partai.

Ada pula kelompok muballig di bawah naungan lembaga-lembaga dakwah seperti Lembaga Dakwah Al-Ishlah, Lembaga Dakwah Al-Mishriyah, Lembaga Dakwah Al-Bayan dan Gerakan Ilham Membawa Berkah (GIMB). GIMB merupakan organisasi dakwah yang dibentuk oleh para pendukung Walikota Makassar, Ilham Arief Sirajuddin yang kelak menjadi sarana sosialisasi sebagai Calon Gubernur Sulawesi Selatan pada Pemilihan Umum Kepala Daerah 2011.

Para muballig di Kota Makassar memanfaatkan organisasi-organisasi tersebut sebagai jaringan informasi peluang dakwah. Informasi itu meliputi waktu penyusunan jadwal khutbah Jumat, jadwal ceramah Ramadhan, jadwal majelis taklim, ceramah takziyah kematian dan lain-lain. Pada informasi dan jaringan itu juga, para muballig mendapatkan referensi tentang peta dakwah yang meliputi latar belakang sosial budaya jamaah pendengar, bentuk layanan panitia dakwah, dan letak geografis tempat dakwah. Pada pertemanan di kelompok itu pula, para muballig mendapatkan pengetahuan tentang hal-hal yang tabu disampaikan ke panitia dakwah, yaitu besaran upah dakwah yang lazim disebut "amplop".

Terlepas pro dan kontra di atas dengan sejumlah dalil dan pembahasannya, yang jelas bahwa semangat penampilan muballig selalu ditentukan oleh besar kecilnya imbalan yang diterima. Perbedaan penerimaan imbkwah mengantarkan muballig untuk selalu bersikap pragmatis dalam pelayanan umat di bidang dakwah. Adanya kluster-kluster, zona-zona atau pengwilayahan dakwah di Kota Makassar menunjukkan bahwa terdapat disparitas muballig. Informasi disparitas itu selalu diperbincangkan dalam diskusi dan pertemuan kelompok muballig yang dalam bentuk formal maupun informal.

Selain sisi-sisi konvensional di atas, dakwah pula sudah memasuki wilayah publisitas yang mengantarkan popularitas muballig karena peliputan media. Sebagai komunitas yang memiliki audiens di Kota Makassar, peliputan media massa terhadap aktifitas muballig kerap dilakukan oleh para jurnalis sehingga terbentuk hubungan semacam simbiosis mutualisme. Jurnalis berkepentingan meliput akatifitas muballig karena perebutan pasar pembaca dan pemirsa. Sedangkan bagi muballig, peliputan media massa akan cepat "mendongkrak" popularitas.

Peluang peliputan kegiatan dakwah, menjadi lahan komersial bagi media sebagai jantung pergerakan usaha penerbitan dan penyiaran pers. Para pekerja pers dengan cekatan dan trampil mengemas kegiatan dakwah itu untuk "dijual" kepada calon pemesan iklan. Pemuatan berita dan iklan menunjukkan bahwa betapa aktifitas muballig menjadi sebuah pusaran dalam pemasaran

Ilmu Dakwah: Academic Journal for Homiletic Studies, Vol. 10 No.2 | Juli-Des 2016201 
media. Pamela Shoemaker (1996) mengemukakan bahwa isi media tidak akan bisa independen dan lepas dari anasir pengaruh individu pekerja media, rutinitas media, kebijakan organisasional seperti kepentingan pemilik, ekstra media dan ideologi.

Para muballig di Kota Makassar sudah terpatri juga kiat-kiat mereka dalam meraih hati khalayak "penikmat" dakwah sehingga sang muballig itu mendapatkan "garansi" untuk diliput oleh media. Pada novel yang ditulis Habiburrahman Al-Syirazi, Dalam Mibrab Cinta, dikisahkan kebanggaan seorang ustaz karena sudah mendapatkan orderan untuk tampil di media televisi. Sang ustaz pun cepat mengabarkan "orderan" kepada sanak famili dan temantemannya untuk menyaksikan tayangan dakwah itu pada jadwal yang telah ditentukan itu.

Pada tahap awal atau lebih lazim disebut muballig populer "pemula, untuk tampil atau diliput oleh media, seorang muballig selalu mendapat rekomendasi dari kelompoknya. Artinya, ketika para jurnalis hendak meliput kegiatan dakwah, maka teman muballiglah yang sepakat mendaulat teman muballignya untuk dijadikan narasumber oleh media itu. Dengan demikian, tatanan sumber daya muballig selalu ditentukan di kelompok muballig, tentang siapa dan di mana seseorang akan tampil. Data di kelompok muballig itu tersedia mengenai "jam terbang" seseorang, sehingga pada tempat-tempat dakwah tertentu selalu disesuaikan dengan tingkat kompetensi seorang muballig, karena perbedaan tempat juga menunjukkan perbedaan layanan dan penghasilan.

Dalam kelompok muballig, setiap orang akan mengambil peran, fungsi dan tugas sesuai dengan kempetensi masing-masing. Ada yang memiliki tingkatan tinggi, menengah dan bawah. Perbedaan tingkatan itu dipandang berdasarkan asas manfaat yang diberikan kepada sesama anggota. Muballig yang memiliki manfaat lebih besar dibanding dengan lainnya, turut serta anggota yang lain mengakui hal itu sebagai perbedaan status sosial di antara para muballig. Pengakuan yang berlangsung secara terus menerus akan melahirkan legitimasi sosial. Legitimasi bermanfaat untuk meningkatkan kehormatan muballig.

Penghormatan terhadap muballig dianggap sebagai penghormatan terhadap ajaran Islam. Muballig merupakan pemegang otoritas untuk menerjemahkan ajaran Islam sebagai penuntun bagi umat Islam dalam kegiatan ibadah dan muamalah. Umat Islam sebagai entitas sosial tidak tampil pada ruang hampa tapi ia berada pada banyak dimensi seperti sosial, politik, ekonomi, budaya dan ideologi. Dari dimensi-dimensi inilah yang mengantarkan muballig juga bergelayut dengan dimensi-dimensi tersebut. Salah satu perwujudan dimensi itu adalah terciptanya strata sosial di kalangan komunitas muballig.

202 Ilmu Dakwah: Academic Joumal for Homiletic Studies, Vol. 10 No.2 | Juli-Des 2016 
Sehubungan dengan permintaan masyarakat tentang aneka penyampaian dakwah, maka muballig pun mengemas penawaran dakwahnya dengan berbagai macam model dan penampilan. Ada yang tampil dengan tematema ilmiah, ada yang menampilkan joke-joke berupa jenaka sehingga tampak pendengar terpingkal-pingkal "ketawa-ketiwi", dan ada pula yang tampil seperti selebriti dengan melantunkan dakwahnya dengan lagu-lagu sehingga pendengar merasa terhibur dengan penampilan muballig ala selebritis itu. Penampilanpenampilan yang berakses pada rangkaian asas permintaan dan penawaran itu, menjadi dakwah memasuki fase fenomena sosial yang banyak melambungkan nama-nama muballig terkenal layak selebritis. Mereka diliput oleh jurnalisjurnalis infotainment karena dipandang dapat menaikkan rating media massa.

Penampilan muballig sering mengikuti keinginan emosional umat Islam, ketika menghadiri kegiatan dakwah. Kegiatan ini dianggapnya sebagai sarana hiburan untuk dikatakan tidak untuk duniawi. Kadang-kadang juga muballig selalu melancarkan retorika yang menyayat dan menyedihkan sehingga pendengar larut dalam kesedihan lalu mereka menangis tersedu-sedu. Muballig merasa dirinya meraih keberhasilan dakwah bilamana mampu membuat tertawa dan menangis orang yang mendengarkan dakwahnya.

Para muballig di arena panggung dakwah berupaya menampilkan kesan yang sesuai dengan kehendak pendengar dakwah. Pelajaran tentang langgamlanggam retorika, pemakaian atribut serta gaya-gaya khas muballig selalu ditampilkan untuk melahirkan kesan yang dapat membuat pendengar untuk terus dipesan ketika ada kegiatan dakwah selanjutnya. Peran kelompok muballig sangat menentukan sebagai basis pembelajaran muballig, karena dengan tukar pengalaman sesama muballig dapat mengantarkan menjadi "ala bisa karena biasa". Pembelajaran dakwah di kelompok muballig selalu ditampilkan berupa simbol-simbol, yang tidak aktif di kelompok itu niscaya tidak mampu memahami "tanda" yang disebarkan oleh sesama muballig lainnya.

Komunitas muballig di Kota Makassar merupakan salah satu komuniats dari beberapa komunitas yang mendiami kota tersebut. Sebagai sebuah komunitas, sudah barang tentu terdapat perlakuan yang berbeda di antara para anggota muballig dalam komunitasnya. Pencapaian sistematika kehidupan sosial yang sudah sampai pada penciptaan stratifikasi sosial pada komunitas itu menunjukkan kemapanan sistem budaya dalam akselerasi sosial masyarakat.

Sebelumnya, penulis juga mengkaji beberapa hasil penelitian yang terkait dengan pola komunikasi kelompok dalam kegiatan dakwah. Upaya menelaah penelitian yang pernah dilakukan peneliti lainnya merupakan panduan bagi penulis untuk mengkaji lebih lanjut tentang pola komunikasi kelompok yang bertalian dengan kegiatan dakwah.

Ilmu Dakwah: Academic Journal for Homiletic Studies, Vol. 10 No.2 | Juli-Des 2016203 
Penelitian Bambang Saiful Ma'arif (2008) tentang Pola Komunikasi Dakwah K.H. Abdullah Gymnastiar dan K.H. Jalaluddin Rahmat Dalam Membina Kehidupan Beragama Jamaabnya di Bandung bersifat kualitatif dengan pendekatan rhetorical critism yang melihat pada figur komunikasi, pesan dan kebahasaannya. Penelitian ini menemukan karakteristik komunikator yang merupakan titik kuat retor dakwah, dimana ia berkaitan dengan gaya komunikasi retor. Gaya komunikasi K.H. Abdullah Gymnastiar yang biasa disebut Aa Gym adalah dramatic dan friendly gaya komunikasi K.H. Jalaluddin Rahmat yang baiasa disebut Kang Jalal adalah contensious dan open. Dakwah Aa Gym membina keyakinan, suasana hati dan kemandirian; Kang Jalal membina sikap inklusif, berpikir kritis dan tanggungjawab dalam bertindak. Pesan komunikasi dakwah Aa Gym bertema ma'rifatullah, akhlak dan kewirausahaan; Kang Jalal mengambil tema akhlak, kebersamaan yang inklusif, sejaran Islam yang kritis dan psikologi agama.

Penelitian Elly Komala (2010) tentang Pola Komunikasi Tingkat Makrifat, menemukan pola zikir sebagai sarana para ulama untuk "manunggaling kawula gusti". Umumnya para ulama mengamalkan bacaan-bacaan zikir tertentu ketika menapaki pendakian spritual. Tanggatangga pendakian spritual dalam kegiatan tasawuf meliputi tobat, sabar, kefakiran, zuhud, tawakkal, mahabbah, makrifat dan ridha.

Penelitian Abd. Kadir Ahmad (2009) tentang Ulama Bugis (Sebuab Kajian Antropologi), menemukan pola komunikasi dakwah kultural. Ulama dalam konstruksi masyarakat Bugis dimaknai sebagai penyambung kosmologis dan teologis sehingga ritual keagamaan dapat terlaksana sebagai bagian kehidupan beragama. Integrasi nilai-nilai keislaman dalam kultur masyarakat Bugis mempengaruhi pola komunikasi dakwah para muballig yang akan mendapatkan legitimasi publik bila mendapat pengakuan dari ulama.

Penelitian ini menggunakan metode Fenomenologi dengan pendekatan kualitatif dengan kajian teoritik komunikasi kelompok yang subyektivis. Penelitian kualitatif adalah penelitian yang bermaksud untuk memahami fenomena tentang apa yang dialami oleh subjek penelitian. Teknik pengumpulan data dalam penelitian fenomenologi adalah dengan wawancara mendalam, refleksi diri dan gambaran relitas di luar konteks penelitian, misalnya dalam novel, puisi, lukisan dan tarian (Creswell dalam Kuswarno, 2009 : 66). Sebagai pelaksanaan dalam penelitian ini, teknik pengumpulan data akan dilakukan melalui observasi partisipatif, wawancara, dan studi dokumentasi.

Sebagai pemeta jalan, penelitian ini menggunakan teori strukturasi dari Anthony Giddens. Teori ini menyatakan bahwa tindakan manusia adalah suatu proses memproduksi atau mereproduksi berbagai sistem sosial (Littlejohn dan

204 Ilmu Dakwah: Academic Journal for Homiletic Studies, Vol. 10 No.2 | Juli-Des 2016 
Fos, 2005, 252). Kelompok-kelompok bertindak menurut aturan-aturan untuk mencapai tujuan-tujuan mereka dan dengan demikian menciptakan strukturstruktur yang kembali mempengaruhi tindakan-tindakan yang akan datang. Struktur-struktur seperti harapan-harapan rasional, peran-peran dan normanorma kelompok, jaringan-jaringan komunikasi, dan institusi-institusi kemasyarakatan mempengaruhi dan dipengaruhi oleh tindakan sosial. Strukturstruktur ini memberi individu aturan-aturan yang memandu tindakan-tindakan mereka, tetapi tindakan-tindakan mereka pada gilirannya menciptakan aturanaturan baru dan mereproduksi aturan-aturan lama .

Teori dramaturgi digunakan untuk pendekatan yang berintikan pandangan bahwa ketika manusia berinteraksi dengan sesamnya, ia ingin mengelola kesan yang ia harapkan tumbuh pada orang lain trehadapnya. Untuk itu setiap orang melakukan pertunjukan bagi orang lain (Mulyana, 2001 : 107), sehingga arena kehidupan ini menurut Goffman layaknya panggung sandiwara. Dengan mengikuti analogi teatrikal, Goffman berbicara mengenai panggung depan (front region) dan panggung belakang (back region).

Teori dramaturgi yang dikemukakan oleh Goffman dianggap tepat untuk menjelaskan realitas dan fenomena relasi komunikasi dalam sebuah komunitas keagamaan yang menjalankan misi suci penyiaran Islam, yang dalam konteks penelitian ini adalah komunitas muballig di Kota Makassar. Dengan menggunakan teori dramaturgi, maka penelitian ini dapat melihat manajemen kesan baik secara verbal maupun non verbal yang dilakukan oleh muballig di Kota Makassar.

Pola komunikasi kelompok pada komunitas muballig di Kota Makassar sangat menarik untuk dikaji lebih jauh sehingga mampu memberikan sumbangan ilmu pengetahuan dari fenomena-fenomena komunitas, untuk pengembangan ilmu komunikasi. Penelitian ini dengan tegas akan mengkaji pola komunikasi kelompok. Adapun tujuan penelitian ini adalah untuk memperoleh gambaran mengenai fenomena komunikasi muballig di kota makasar, bagaimana pengelolaan kesan dan penampilan Muballig di Kota Makassar, dan bagaimana pula pola terintegrasi dalam komunikasi kelompok pada Komunitas Muballig di Kota Makassar

\section{HASIL DAN PEMBAHASAN}

Muballig hadir dalam kehidupan sosial yang kemudian tampil menyampaikan dakwah sesuai dengan pemahaman yang sudah "disetting" oleh lembaga-lembaga pendidikan, organisasi dan kajian keislaman yang menempanya. AGH. M. Sanusi Baco, mantan Ketua DPW Nahdlatul Ulama (NU) Sulawesi Selatan, kini menjadi muballig NU, Ustaz Ilyas Upe, alumni Madrasah As'adiyah kini menjadi muballig di bawah naungan kelompok As'adiyah. Ustaz M. Alim Ihsan, mantan pengurus Ikatan Mahasiswa 
Muhammadiyah (IMM), kini menjadi muballig Muhammadiyah. Ustaz Sadiq Syukur yang aktif mengikuti kegiatan khuruj, kini menjadi muballig Jamaah Tablig. Begitu seterusnya pada ribuan muballig di Kota Makassar.

Pengalaman-pengalaman para muballig dengan latar belakang yang bermacam-macam itu, menampilkan pula macam ragam ideologi yang dianutnya. Ketika penulis menemui beberapa muballig NU, dengan tegas mereka menyatakan bahwa Ahlussunnah Waljamaah sudah menjadi "harga mati" untuk terus didakwahkan dalam rangka mewujudkan Islam yang menjadi rahmat seluruh alam (rahmatan lil 'alamin). Para muballig Muhammadiyah, juga dengan tegas menyatakan bahwa untuk membersihkan aqidah umat Islam, harus dengan memberantas Takhyul, Bid'ah dan Churafat (TBC). Demikian pula para peserta muballig Jamaah Tablig, menyatakan bahwa khuruj adalah ideologi dakwah yang harus dilestarikan oleh semua pekerja dakwah.

Untuk pemetaan tentang ideologi dakwah para muballig di Kota Makassar, dapat dilihat pada tabel berikut :

Tabel 1.

Pola Komunikasi pada Ideologi Muballig

\begin{tabular}{|l|l|l|c|c|c|c|c|c|}
\hline \multirow{2}{*}{ No } & \multirow{2}{*}{$\begin{array}{l}\text { Varian } \\
\text { Muballig }\end{array}$} & $\begin{array}{l}\text { Muham- } \\
\text { madiyah }\end{array}$ & NU & DDI & TN & HTI & PKS & JT \\
\hline 1 & Ulama & Anti TBC & Aswaja & Berkah & Makrifatullah & Khilafah & $\begin{array}{l}\text { Islam dan } \\
\text { Pancasila }\end{array}$ & Khuruj \\
\hline 2 & Ustaz & Anti TBC & Aswaja & Berkah & Makrifatullah & Khilafah & $\begin{array}{l}\text { Islam dan } \\
\text { Pancasila }\end{array}$ & Khuruj \\
\hline 3 & $\begin{array}{l}\text { Guru } \\
\text { Mengaji }\end{array}$ & Anti TBC & Aswaja & Berkah & Makrifatullah & Khilafah & $\begin{array}{l}\text { Islam dan } \\
\text { Pancasila }\end{array}$ & Khuruj \\
\hline
\end{tabular}

Keterangan :

$\begin{array}{ll}\text { 1. NU } & \text { : Nahdlatul Ulama } \\ \text { 2. DDI } & \text { : Darul Da'wah wal Irsyad } \\ \text { 3. TN } & \text { : Tarikat Naqsyabandiyah } \\ \text { 4. HTI } & \text { : Hizbut Tahrir Indonesia } \\ \text { 5. PKS } & \text { : Partai Keadilan Sejahtera } \\ \text { 6. JT } & \text { : Jamaah Tablig } \\ \text { 7. TBC } & \text { : Takhyul, Bid'ah dan Churafat } \\ \text { 8. Aswaja } & \text { : Ahlussunnah Waljamaah }\end{array}$

Tabel di atas menunjukkan bahwa muballig sudah terpetakan pada beberapa pandangan ideologi yang sudah dibangun oleh organisasi yang menaunginya. Organisasi massa Muhammadiyah memilih ideologi dakwah

206 Ilmu Dakwah: Academic Journal for Homiletic Studies, Vol. 10 No.2 | Juli-Des 2016 
yakni pemberantasan terhadap hal-hal yang dapat menggelincirkan umat Islam dari kemurnian akidah kepada Allah SWT. Dirumuskanlah anonim TBC yang juga identik dengan penyakit fisik yang sangat susah disembuhkan yaitu Tubercholisis disingkat TBC. Anti TBC dalam ideologi dakwah Muhammadiyah yaitu Takbyul, Bid'ah dan Churafat (C dibaca $\mathrm{K}$ dalam ejaan lama bahasa Indonesia). Takhyul adalah mempercayai ada kekuatan dan kekuasaan selain Allah SWT. Bid'ah adalah amalan dalam ibadah yang tidak ada petunjuknya dalam Al-Qur'an dan Hadis. Sedangkan churafat adalah praktek perdukunan yang dijadikan washilah untuk menyampaikan doa dan harapan kepada Sang Pencipta.

NU memilih ajaran ablusunnah waljamaah sebagai ideologi yang kemudian diikuti dan dijadikan haluan dakwah bagi muballignya. Ablussunnah waljamaah adalah pengikut sunnah Rasulullah SAW dan dianut oleh mayoritas (jamaah) umat Islam. DDI memilih kharimatika pendirinya AGH. Ambo Dalle sebagai sebagai ideologi dakwah muballignya. Antusias umat Islam massa DDI untuk memburu berkah kepada AGH. Ambo Dalle semasih hidup terus dihidupkan oleh muballignya untuk tetap dapat memelihara dan mempertahankan anggota organisasi. As'adiyah memilih pengkhidmatan kepada ilmu pengetahuan agama Islam yang bersumber dari kitab kuning sebagai haluan organisasi. As'adiyah yang merupakan penisbahan dari AGH. Muhammad As'ad, dikukuhkan oleh MUI Sulawesi Selatan sebagi gurunya para ulama di propinsi ini.

TN memilih ajaran tasawuf yaitu makrifatullah sebagai ideologi organisasi. HTI memilih jargon penegakan khilafah sebagai haluan perjuangan yang terus-menerus didakwahnkan oleh muballignya. PKS yang memilih ideologi Islam terus diejawantahkan dalam simbol "bersih, peduli, profesional" sebagai partai Islam modern dan terbuka. JT menjadikan kegiatan khuruj (keluar dari kampung halaman untuk berdakwah) sebagai basis ideologi. Sentrum dakwah Jamaah Tablig adalah khuruj. Setiap pertemuan pengajian yang dilakukan oleh Jamaah Tablig, khuruj menjadi wujud dakwah yang harus diamalkan oleh semua anggota. Khuruj itu terdiri atas tiga hari, tujuh hari, 40 hari hingga tiga bulan lamanya.

AGH. Said Abd. Samad, seorang ulama HTI menyatakan kepada penulis bahwa zaman terbaik (khair al-qurumn) dalam perjalanan dakwah adalah zaman di mana Rasulullah SAW hidup (qarniy). Di sini sangat jelas bahwa ulama HTI menjadikan putra Abdullah itu sebagai tokoh yang menginspirasi perjuangan untuk membentuk daulah Islamiyah yakni khilafah. Kenapa demikian, karena cucu Abdul Muttalib itulah yang menelorkan sistem pemerintahan khilafah. Sedangkan para ustaz dan guru mengaji DDI yang memang mayoritas alumni Pondok Pesantren DDI Mangkoso dalam 
wawancara dengan penulis menyatakan bahwa sosok AGH. Farid Wajdi adalah seorang ilmuan yang patut menjadi sumber inspirasi dalam berdakwah.

Adapun pemetaan tentang tokoh inspiratif pada komunitas muballig di Kota Makassar, dapat dilihat pada tabel berikut :

Tabel 2.

Pola Komunikasi pada Inspirasi Muballig

\begin{tabular}{|c|c|c|c|c|c|c|c|c|}
\hline \multirow[b]{2}{*}{ No } & \multirow{2}{*}{$\begin{array}{c}\text { Varian } \\
\text { Muballig }\end{array}$} & \multicolumn{7}{|c|}{ Tokoh Inspiratif } \\
\hline & & $\begin{array}{l}\text { Muham- } \\
\text { madiyah }\end{array}$ & NU & DDI & $\mathbf{T N}$ & HTI & PKS & JT \\
\hline 1 & Ulama & $\begin{array}{l}\text { K.H. } \\
\text { Ahmad } \\
\text { Dahlan }\end{array}$ & $\begin{array}{l}\text { Imam } \\
\text { Syafii }\end{array}$ & $\begin{array}{l}\text { AGH. } \\
\text { Ambo } \\
\text { Dalle }\end{array}$ & $\begin{array}{l}\text { Syekh } \\
\text { Yusuf }\end{array}$ & Rasulullah & $\begin{array}{l}\text { Hasan } \\
\text { Al- } \\
\text { Banna }\end{array}$ & $\begin{array}{l}\text { Muhammad } \\
\text { Ilyas } \\
\text { Kandahlawi }\end{array}$ \\
\hline 2 & Ustaz & $\begin{array}{l}\text { K.H. Bakri } \\
\text { Wahid }\end{array}$ & $\begin{array}{l}\text { AGH. } \\
\text { Sanusi } \\
\text { Baco }\end{array}$ & $\begin{array}{l}\text { AGH. } \\
\text { Farid } \\
\text { Wajdi }\end{array}$ & $\begin{array}{l}\text { AGH. } \\
\text { Puang } \\
\text { Rammang }\end{array}$ & $\begin{array}{l}4 \text { orang } \\
\text { khalifah }\end{array}$ & $\begin{array}{l}\text { KH. } \\
\text { Rahmat } \\
\text { Abdullah }\end{array}$ & $\begin{array}{l}\text { Muhammad } \\
\text { Ilyas } \\
\text { Kandahlawi }\end{array}$ \\
\hline 3 & $\begin{array}{l}\text { Guru } \\
\text { Mengaji }\end{array}$ & $\begin{array}{l}\text { K.H. Bakri } \\
\text { Wahid }\end{array}$ & $\begin{array}{l}\text { AGH. } \\
\text { Sanusi } \\
\text { Baco }\end{array}$ & $\begin{array}{l}\text { AGH. } \\
\text { Farid } \\
\text { Wajdi }\end{array}$ & $\begin{array}{l}\text { AGH. } \\
\text { Puang } \\
\text { Rammang }\end{array}$ & $\begin{array}{l}4 \text { orang } \\
\text { khalifah }\end{array}$ & $\begin{array}{l}\text { KH. } \\
\text { Rahmat } \\
\text { Abdullah }\end{array}$ & $\begin{array}{l}\text { Muhammad } \\
\text { Ilyas } \\
\text { Kandahlawi }\end{array}$ \\
\hline
\end{tabular}

Berdasarkan tabel di atas, menunjukkan bahwa tokoh inspiratif sangat mempengaruhi pola komunikasi setiap kelompok muballig. Kalangan ulama Muhammadiyah menjadikan tokoh pembaru KH. Ahmad Dahlan sebagai tokoh inspiratif. Sedangkan di kalangan ustaz dan guru mengaji menjadikan KH. Bakri Wahid, tokoh Muhammadiyah Propinsi Sulawesi Selatan sebagai tokoh yang menginspirasi dalam dakwah yang menyejukkan. Kalangan ulama NU menjadikan Imam Syafii sebagai ulama besar yang luas ilmunya sebagai tokoh inspiratif. Mazhab Syafiiyah adalah mazhab fiqh yang ajarannya sangat dipatuhi di kalangan massa NU. Di kalangan ustaz dan guru mengaji memilih dan sangat mengelukkan AGH. Sanusi Baco sebagai tokoh inspiratif mereka.

Para ulama DDI sangat memuliakan AGH. Ambo Dalle sebagai tokoh kharismatik yang selalu diikuti fatwa dan pandangan keilmuannya. Di kalangan ustaz dan guru mengaji DDI selalu menyebut KH. Farid Wajdi sebagai tokoh yang sangat dikagumi oleh umat Islam Makassar. Para ulama As'adiyah menjadikan AGH. Muhammad As'ad, ulama besar Sulawesi Selatan sebagai guru yang mulia. Kalangan ustaz dan guru mengaji memilih AGH. Muhammad Nur, pengasuh Pondok Pesantren Darul Qur'an Makassar.

Ulama TN senantiasa melestarikan ajaran tarikat muktabarah Syekh Yusuf, ulama besar, pahlawan nasional Afrika Selatan dan Indonesia yang pertama kali membawa ajaran tarikat di Makassar. Kalangan ustaz dan guru mengaji selalu terinspirasi dari keistiqamahan AGH. Puang Rammang dalam melestarikan ajaran tarikat di Kota Makassar hingga sekarang. Ulama HTI selalu

208 Ilmu Dakwah: Academic Joumal for Homiletic Studies, Vol. 10 No.2 | Juli-Des 2016 
mengumandangkan "romantisme" umat Islam di zaman Rasulullah SAW. Sedangkan ustaz dan guru mengaji anggota HTI selalu menampilkan empat orang khalifah dari pemerintahan Khulafaurrasyidin sebagai zaman yang cocok diterapkan dalam rangka menegakkan Daulah Islamiyah sebagai "payung" penegakan syariat Islam.

Ulama PKS terinspirasi dari gerakan Ikhawanul Muslimin di Mesir, salah seorang tokohnya adalah Hasan Al-Banna. Sedangkan ustaz dan guru mengaji PKS yang aktif melakukan mentoring pengajian Islam selalu merindukan sosok murabbi dan mantan Ketua Dewan Syuro PKS, K.H. Rahmat Abdullah. Kemudian ulama, ustaz dan guru mengaji JT selalu menyebut tokoh inspiratif Muhammad Ilyas Kandahlawi, pendiri JT di India pada tahun 1925. Kandahlawi membentuk gerakan dakwah dengan cara mengunjung saudara umat Islam yang belum tersentuh dakwah dengan sebutan khuruj fi sabilillah.

Setelah para muballig menghadirkan realitas kehidupan mereka di bidang ideologi dan inspirasi, fenomena identitas para muballig juga tidak terlepas dari penampilan mereka di arena "panggung" dakwah di Kota Makassar. Konstruksi internasionalisasi isu tentang Islam yang kemudian direduksi menjadi gerakan dakwah turut pula mewarnai identitas muballig di Kota Makassar.

Reduksi realitas dakwah secara global dapat dikategorikan dengan sebutan radikal, moderat, dan liberal. Dalam menjalani realitas dakwah tersebut, muballig di Kota Makassar memiliki kreatifitas untuk menyiasatinya. Trend global yang menampilkan wajah Islam globalistik diaplikasikan dalam bentuk identitas penampilan. Salah satu identitas penampilan itu adalah gaya berbusana. Barnard (2006 : xiv) menyajikan fashion dan pakaian sebagai cara mengkomunikasikan identitas-identitas kelas, gender, seks, dan sosial.

Ketika penulis melakukan konfirmasi tentang stigma radikal, moderat dan liberal, Ustaz "RA" menyebutnya sebagai dinamika dakwah yang senantiasa mengiringi kehidupan sosial masyarakat. Makassar yang diagendakan menjadi "Kota Dunia" tentu tidak bisa terlepas dari pertarungan global yang sudah pasti memiliki implikasi dalam kegiatan dakwah. Dengan demikian banyak sajian dakwah, lalu dipersilakan masyarakat untuk memilihnya.

Ketika penulis bertemu dengan beberapa orang muballig dari kelompok Jamaah Tablig menyebutkan bahwa kalau memang radikal bermakna pemahaman yang asli tentang Islam, maka umat Islam harus mengamalkan ajaran Islam secara radikal. Umat Islam tidak boleh terpengaruh dengan ajaran yang berasal dari luar Islam. Seperti halnya penampilan yang hal memilih pakaian, sejumlah muballig Jamaah Tablig menyebutkan bahwa pemeliharaan jenggot merupakan sunnah Rasulullah SAW yang tidak pernah terputus pahalanya. Ustaz "SSy" memaparkan bahwa setiap amalan yang berhenti

Ilmu Dakwah: Academic Journal for Homiletic Studies, Vol. 10 No.2 | Juli-Des 2016209 
dilakukan ataupun diucapakan, akan berhenti pula pahalanya. Akan tetapi pemeliharaan jenggot, sepanjang hal itu masih bergantung di dagu, pahalanya akan mengalir terus. Inilah amalan yang sangat ringan namun pahalanya jalan terus. Biar kita masuk ke toilet sekalipun, pahala jenggot akan tetap mengalir.

Stigma radikal dialamatkan pula kepada pengusung jargon khilafah, yaitu Hizbut Tahrir Indonesia. Ketika hal itu dikonfirmasi ke salah seorang muballig HTI, Ustaz "MAm" dengan lugas menyebut hal itu sebagai tantangan perjuangan. Menurut beliau, perjuangan menegakkan syariat Islam memang tidak pernah lepas dari tantangan, yang justru datang dari internal umat Islam itu sendiri. Hal tersebut sejalan dengan ungkapan, al-Islam mabjubun lil muslimin (Islam terhalang sendiri oleh umat Islam) (wawancara, 2 Mei 2011).

Sejalan dengan hasil negosiasi di atas, Kompas (20 Mei 2011) menurunkan sebuah berita, yaitu :

... perjuangan khilafah Islam yang didorong kelompok tertentu di Indonesia identik dengan gagasan mendirikan gagasan mendirikan negara di atas negara. Hal tersebut mencerminkan penolakan terhadap keberadaan NKRI berdasarkan Pancasila. Di Timur Tengah, gagasan semacam ini dianggap sebagai gerakan radikal sehingga kemudian dilarang.

Identitas keislaman pada istilah moderat, liberal, dan radikal mendapatkan tanggapan dari novelis Habiburrahman El-Syirazi (2009 : 36), dengan mengemukakan bahwa yang radikal, moderat dan liberal adalah pemahaman dan penghayatan manusia atas Islam. Pemahaman yang ditampilkan dalam bentuk gerakan dan pakaian, selang bersambut dalam konteks pemaknaan dalam simbol yang langsung dilihat secara nyata. Kenyataan itulah yang menegaskan adanya identitas muballig pada ketiga kategori itu.

Untuk melihat gambaran tentang identitas muballig di Kota Makassar, dapat ditemukan pada tabel berikut ini :

Tabel 3.

Pola Komunikasi pada Identitas Muballig

\begin{tabular}{|c|c|c|c|c|c|c|c|c|}
\hline No & Varian & \multicolumn{9}{|c|}{ Corak Identitas } \\
\cline { 3 - 8 } & Muballig & $\begin{array}{c}\text { Muham } \\
\text { madiyah }\end{array}$ & NU & DDI & TN & HTI & PKS & JT \\
\hline 1 & Ulama & Moderat & Moderat & Moderat & Moderat & Moderat & Moderat & Moderat \\
\hline 2 & Ustaz & $\begin{array}{c}\text { Moderat/ } \\
\text { Liberal }\end{array}$ & $\begin{array}{c}\text { Moderat/ } \\
\text { Liberal }\end{array}$ & Moderat & Moderat & Radikal & Radikal & Radikal \\
\hline 3 & $\begin{array}{c}\text { Guru } \\
\text { Mengaji }\end{array}$ & Moderat & Moderat & Moderat & Moderat & Radikal & Radikal & Radikal \\
\hline
\end{tabular}

Pada tabel di atas menunjukkan bahwa seluruh ulama di Kota Makassar, dengan kedalaman ilmu pengetahuan selalu mengedepankan dialog

210 Ilmu Dakwah: Academic Journal for Homiletic Studies, Vol. 10 No.2 | Juli-Des 2016 
dengan hikmah kebijaksanaan ketika menghadapi persoalan dakwah di kalangan umat Islam. Sikap moderat para ulama itu diikuti oleh banyak ustaz dan guru mengaji dari berbagai kelompok muballig.

Namun demikian, ada beberapa kalangan ustaz yang menganut corak liberal dalam menerjemahkan ajaran Islam dalam kehidupan sosial. Hal itu ditemukan pada ustaz Muhammadiyah dan NU. Pelopor liberal di Muhammadiyah dipelopori oleh Jaringan Islam Muda Muhammadiyah (JIMM) dan pelopor liberal di kalangan NU adalah Jaringan Islam Liberal (JIL).

Sedangkan corak radikal ditemukan di kalangan ustaz dan guru mengaji HTI, PKS dan JT. Corak kekhasan mereka dalam mengartikulasikan (memahami dan mengamalkan) ajaran Islam merupakan bagian dari dinamika dakwah. Ada yang moderat yang secara lugas dalam dialog dengan pihak manapun. Ada yang liberal sebagai wujud implementasi keilmuan modern. Sedangkan yang radikal adalah orang-orang yang istiqamah mempertahankan teks-teks ajaran Islam.

Identitas radikal muballig yang ditampilkan dengan busana, merupakan langkah nyata perlawanan terhadap kemapanan sosial budaya yang sangat ketat dipelihara oleh masyarakat Bugis Makassar. Budaya busana itu berupa peci hitam bagi yang belum naik haji. Peci putih dan sorban bagi masyarakat Makassar dapat dipakai oleh seseorang bilamana sudah menunaikan ibadah haji.

Muballig sebagai agen pemasaran dakwah, sebagaimana pemasaran jasa lainnya. Rhenald Kasali (2001 : 145) menyebut cara pemasaran telekomunikasi dengan adaptif dan radikal. Radikal bagi sebagian muballig di Kota Makassar bukan sesuatu yang destruktif melainkan wahana ciri khas yang ditampilkan muballig sesuai dengan gaya dan talentanya. Radikal sebagaimana yang distigmakan dengan kekerasan berupa penyerangan tempat-tempat ibadah, pemboman dan lain-lain, bukan makna radikal tapi itu adalah tindakan kriminal. Sewaktu terjadi tragedi Bom Bali I, sejumlah orang-orang Jamaah Tablig asal Makassar yang melakukan khuruj di Pulau Bali langsung ditahan oleh polisi karena "stigma assosiatif", namun dilepas karena tidak ada bukti keterlibatan walaupun busana dipakai dimaknai sama dengan yang dipakai oleh oknum pelaku bom.

\section{Pengelolaan Kesan dan Penampilan Muballig di Kota Makassar}

Pengelolaan dakwah merupakan tindakan profesional. Seseorang yang menjadi komunikator dakwah adalah orang-orang yang memiliki keahlian khusus di bidang penyiaran agama Islam. Keahlian itu meliputi penguasaan materi pengetahuan tentang ajaran Islam, keahlian retoris, dan kemampuan "pemasaran" dakwah. Argumen ini menunjukkan terjadinya asumsi dramaturgis 
dalam realitas muballig yang menjadikan profesi dakwah sebagai tindakan sosial yang dipersiapkan untuk memenuhi keinginan dan "selera" khalayak.

Pengaruh retorika itu pula melahirkan spesialis keilmuan dalam studi Islam yang disebut Ilmu Balâgah, yaitu ilmu yang membahas tentang persesuaian antara kalimat demi kalimat dalam bahasa Arab. Kemudian turunannya lahir panduan beragumen dan berdebat, Adab Al-Babz Wa Al-Munazarah. Balaggab yang seakar kata dengan muballig dalam bahasa Arab, dapat diasumsikan bahwa dengan Ilmu Balâgah, para muballig dengan penggunaan retorika semakin menambah dinamika penyampaian ajaran Islam.

Ketika ilmu komunikasi dipakai untuk menyorot kegiatan dakwah, maka kajian tentang tablig dan muballig akan menampilkan telaah ilmiah bahwa teori dramaturgis dapat dipergunakan untuk membahas manajemen kesan yang dilakukan oleh ulama, ustaz dan guru mengaji di Kota Makassar. Adapun manajemen kesan dalam pembahasan ini meliputi kesan berwibawa, humoris, dan menggurui.

Berwibawa merupakan upaya untuk memperoleh kesan ketika tampil berdakwah, Ustaz "SD" mengakui telah banyak menerima wejangan khusus dari gurunya, berupa bacaan khusus yang diamalkan sehingga tidak mengalami kejadian "nervous" di depan khalayak umat Islam. Adapula paket "bacaan" yang diterimanya untuk terus dicintai oleh pemakai jasa dakwah.

Paket-paket "bacaan" atau "ritual-ritual" tertentu diamalkan oleh muballig dengan dalih untuk kesuksesan berdakwah. Hal ini dilakukan karena tampil berbicara di depan khalayak atau massa dapat menyedot rangkaian emosional seorang komunikator. Seorang muballig yang tidak mampu percaya diri ketika tampil berdakwah dapat saja membuat kekecewaan para pendengarnya, sehingga menyebabkan "pasaran" untuk tampil selanjutnya tidak berlangsung sukses.

Kesan penampilan berwibawa muballig dimaksudkan untuk membuat ajaran Islam itu didengar dan dipatuhi oleh umat Islam. Muballig identik dengan ajaran Islam itu sendiri. Artinya wajah Islam selalu ditampilkan oleh orangorang yang selalu mengingatkannya. Oleh karena itu perlu dengan penguasaan materi dakwah baru kemudian tampil berceramah. Sebuah anekdot yang selalu disampaikan pada pelatihan muballig/muballigah, adalah bilamana anda menguasai 100\% materi dakwah maka akan tinggal 75\% ketika anda tampil berceramah. Ketika penguasaan hanya 75\%, maka akan tampil maksimal 50\%. Begitu seterusnya, karena dalam penampilan di depan umum maka akan berpadu dengan perasaan emosional disebabkan oleh aura orang banyak di depan kita.

Kewibawaan adalah suatu pengaruh yang diakui kebenaran dan kebesaranny, bukan sesuatu yang memaksa (Sadulloh, 2010 : 165). Kewibawaan harus berbanding dengan ketidakmampuan audiens, jika kemampuan muballig

212 Ilmu Dakwah: Academic Journal for Homiletic Studies, Vol. 10 No.2 | Juli-Des 2016 
tersebut sukar ditegakkan. Dengan demikian kewibawaan muballig akan diakui bilamana yang bersangkutan mempunyai kelebihan di bidang dakwah, baik sikap, pengetahuan dan pengamalan agama.

Kewibawaan seseorang tercapai bilamana ditopang oleh kedewasaan jasmaniah dan kedewasaan rohaniah. Kedewasaan jasmaniah tercapai apabila seseorang telah mencapai puncak perkembangan jasmani yang optimal. Kedewasaan rohaniah tercapai apabila seseorang telah memiliki cita-cita hidup dan pandangan hidup yang tetap. Cita-cita dan pandangan hidup telah menjadi milik dirinya, dan sekaligus berusaha untuk melaksanakannya dalam perilaku dan perbuatan kehidupannya.

Sehubungan dengan kesan berwibawa yang ditampilkan oleh komunitas muballig, Mulyana (2008 :122) menyebut "penggunaan tim", sehingga penelitian di Makassar dapat dikategorikan dalam kajian dramaturgis Goffman. Fokus perhatian Goffman sebenarnya bukan hanya individu, tetapi juga kelompok atau apa ia sebut tim. Selain membawakan peran dan karakter secara individu, aktor-aktor sosial juga berusaha mengelola kesan orang lain terhadap kelompoknya, baik itu keluarga, tempat bekerja, partai politik, atau organisasi lainnya yang mereka wakili.

Pengelolaan kesan (impression management) dalam teori dramaturgis pada komunitas muballig hampir sama "serunya" dengan komunitas komedian, sandiwara dan perfilman. Muballig memahami bahwa ajang kelompok sebagai panggung belakang (back stage) dan penampilan dakwah di masyarakat sebagai panggung depan (front stage). Oleh karena itu muballig tidak hanya sekadar membaca kitab-kitab ulama klasik dan modern tapi juga menyempatkan diri membaca majalah fashion, majalah sex, majalah desain grafis, koran umum, koran kriminal, koran hiburan dan sebagainya. Tontonan di televisi terkadang harus disimak seperti sinetron, telenovela, berita dan sebagainya karena itu akan menjadi bahan ceramah ketika suasana tampak menjenuhkan.

Pada pengamatan penulis yang mengikuti beberapa kegiatan dakwah di Kota Makassar, arena kelompok menjadi ajang pembelajaran bagi grup-grup muballig. Materi-materi dakwah humoris sering dikemukakan oleh beberapa muballig, seperti bahan lelucon berikut ini :

"Sama Mamamu mo kau belajar mengaji, karena dia itu pintar mengaji dan dari naik haji lagi. Begitu sang anak mendatangi Mamanya. Sang Mama menyahut, sama Bapakmu mo, dia itu juara MTQ kecamatan" (Ustaz Amri Amir dan Ustaz Dasa'at Latif). Dalam suasana yang assosiatif bagi masyarakat Makassar sontak mengundang ketertawaan, karena argumen itu menunjukkan bahwa ada orang sudah bergelar "Haji/Hajjah" namun belum tahu mengaji.

Dramaturgis pada hakikatnya adalah mencari tahu tentang "bagaimana" sesuatu dilakukan bukan "mengapa" sesuatu itu dilakukan (Mulyana, 2001 : 132). Oleh sebab itu setiap muballig pada dasarnya akan 
menampilkan sosok diri yang ideal sesuai dengan perannya. Sekuat tenaga mereka akan menyembunyikan fakta dan motif yang tidak sesuai dengan citradirinya baik melalui penampilan (appearance) maupun melalui gaya (manner) nya. Mereka yang berpenampilan fisik lengkap dengan gamis dan sorbannya lalu berkomunikasi dengan jujur dan percaya diri dianggap tengah mementaskan dua hal itu. Semua hal itu memang tampak di panggung depan.

Di panggung belakang, peran itu bisa bergeser seketika, di mana muballig sedang duduk bersandar di belakang mimbar atau podium. Pada posisi itu, muballig dapat melepaskan sorban dan bahkan pecinya sekalipun lalu dengan santai berkipas, bercengkerama dengan panitia masjid atau dengan kumpulan orang lain yang berada di ruangan itu. Berbeda halnya jika muballig tampil di majelis taklim yang melibatkan peserta dakwah yang permanen meinta muballig untuk berdialog, maka panggung depan menjadi arena bukan hanya muballig tapi juga dari anggota majelis taklim yang taat dengan "kode etik" atau tatakrama lembaganya.

Audiens dakwah merupakan massa yang harus dikendalikan suasan emosionalnya oleh muballig. Muballig yang sudah memiliki branding dengan pola pencitraan sebagai muballig yang suka menampilkan lelucon pada setiap kali tampil berdakwah, maka audiens selalu menunggu joke-joke segarnya sehingga suasana menjadi cair dan tidak menjenuhkan.

Kesan menggurui juga dapat dijumpai pada kegiatan khutbah Jumat. Kesakralan khutbah yang dimasukkan sebagai dua rakaat, membuat jamaah Jumat untuk menerima apa adanya dari penyampaian khatib. Di tengah kekhusyuan, sering khatib terlena dengan waktu yang menimbulkan "kepanikan" jamaah. Pada kondisi demikian, ada khatib yang berseru di mimbar bahwa mendengar khutbah hanya sekian menit, namun ketika berada di rumah dengan kegiatan yang tidak jelas pahalanya tidak dirasa waktu berlalu.

Tanggapan jamaah sering dilampiaskan dengan simbol-simbol kebosanan, seperti berdehem, mengucapkan "amin" yang talu-talu, duduk sambil merangkul lutut dan lain-lain. Pada kondisi demikian, ada khatib yang langsung mengerti "kegerahan" jamaah, kemudian langsung mengucapan "barakah Allah liy wa laku fil Qur'an al-"Azim", kemudian segera duduk untuk berdiri lagi menyampaikan khutbah kedua. Ada juga khatib yang tidak memerdulikannya, karena menganggap bahwa duduk mendengar khutbah Jumat adalah bagian dari ibadah Shalat Jumat.

Kajian dramaturgis dapat diamati dari pandangan Mulyana (2008 : 128) bahwa seseorang dianggap mempunyai atau menjaga wajahnya ketika ia secara efektif menampilkan citra diri yang konsisten secara internal, yang ditopang oleh penilaian dan bukti yang dimiliki orang lain yang tidak berkepentingan. Menampilkan wajah yang layak adalah bagian dari tata krama situasional, yakni aturan-aturan mengenai kehadiran diri yang harus dikomunikasikan kepada

214 Ilmu Dakwah: Academic Journal for Homiletic Studies, Vol. 10 No.2 | Juli-Des 2016 
orang lain yang juga hadir. Aturan ini harus dibedakan dengan aturan mengenai aspek kehidupan lainnya meskipun terkadang berlaku pada saat yang sama, misalnya aturan hukum yang mengatur masalah ekonomi, dan politik atau kode etik yang mengatur profesi.

Kesan muballig tersebut biasa berbeda dengan penampilannya ketika berada di kelompoknya. Ulama ini sering diam mendengar teman-teman muballig bercengkrama dengan masalah-masalah aktual kedakwahan. Kesan menggurui di mimbar khutbah Jumat tidak tampak kesan itu ketika berada di tengah-tengah kelompoknya. Muballig yang demikian memilih kesan itu karena tidak memiliki kepentingan untuk mendaptkan sanjungan dan pujian dari khalayak.

\section{Pola Terintegrasi Komunikasi Kelompok Komunitas Muballig}

Kajian tentang komunikasi kelompok didasarkan pada tradisi komunikasi lisan yang dilakukan oleh orang-orang yang berhimpun pada sebuah kelompok kecil. Pola pengambilan keputusan yang dilakukan oleh para anggota kelompok merupakan ciri khas keberadaan kelompok itu. Saefullah (2007 : 241) mengemukakan bahwa sedikitnya ada tiga macam teknik dalam pengambilan keputusan melalui kelompok, yaitu interacting groups, delphi groups dan nominal groups.

Interacting groups adalah suatu pembuatan keputusan kelompok paling popular, baik berupa kelompok tetap ataupun kelompok yang dibuat khusus. Antara lain berupa suatu bagian fungsional, tim kerja reguler, standing committee, ad hoc committee task forces, dan sebagainya. Anggota-anggota kelompok berbicara antara mereka, saling menyampaikan pandangan, memberikan argumentasi, berdiskusi dan mencari kesepahaman sampai pada kesepakatan untuk mengambil keputusan.

Delphi groups adalah suatu bentuk pembuatan keputusan kelompok yang dibuat melalui pandangan-pandangan berbagai ahli atau pakar. Pakar-pakar tersebut memberikan pendapat dan opininya secara bebas berdasarkan pemikiran dan hasil penelitiannya masing-masing. Tahap pertama dalam metode ini adalah memperoleh suatu kerja sama suatu panel of experts dari berbagai bidang kepakarannya. Pakar atau experts tersebut bisa terdiri dari para peneliti, akademisi, konsultan, para eksekutif yang relevan dengan permasalahan. Mereka diminta untuk memberikan prediksi dan pendapat masing-masing secara tertulis dengan tidak menyebutkan namanya. Tanggapan masing-masing pakar dikumpulkan dan kemudian disampaikan kepada semua anggota kelompok untuk diminta kembali pendapat dan prediksinya masing-masing. Selanjutnya tanggapan mereka diinventarisasi dan dikelompokan sehingga diperoleh adanya tanggapan yang bersifat ekstrim atau tidak biasa. Tanggapan yang berbeda tersebut disampaikan kembali kepada para anggota untuk diberikan justifikasi 
dan solusi sehingga tanggapan-tanggapan yang muncul terkristalisasi dan dianggap sebagai keputusan bersama.

Nominal groups adalah suatu tehnik pengambilan keputusan secara terstruktur yang digunakan untuk menghasilkan pilihan-pilihan kreatif dan inovatif. Setelah suatu kelompok dibentuk kemudian diberi penjelasan mengenai masalah yang memerlukan pemecahan dan keputusan. Para anggota kelompok diminta untuk memberikan pilihan sebanyak-banyaknya secara tertulis berdasarkan pemikirannya masing-masing secara bebas tetapi tidak berbicara atau memperbincangkan dengan anggota lainnya. Kemudian pilihanpilihan mereka diinventarisasi dan dibuat dalam suatu tabel atau daftar dan dibuka diskusi bersama. Terakhir anggota kelompok diminta untuk memilih salah satu pilihannya dan disusun secara tally sehingga diperoleh urutan atau rangking dari pilihan-pilihan tersebut. Pilihan dengan rangking tertinggi atau urutan pertama dianggap sebagai keputusan kelompok.

Muballig sebagai public figure yang kemudian menghimpunkan diri mereka dalam sebuah wadah kelompok, tentunya sudah pasti akan terikat oleh keputusan yang telah ditetapkan oleh kelompoknya. Keputusan yang lazim diambil adalah penentuan jadwal ceramah atau khutbah. Prinsip samina wa ata'na (mendengar keputusan dan mengikutinya) merupakan komitmen yang dipegang oleh setiap anggota.

Sebagai penelitian yang bersifat induktif, komunitas muballig yang menampilkan diri mereka dalam performa profesionalitas selalu memolakan komunikasinya dalam bentuk terintegrasi. Ulama yang memiliki otoritas tertinggi dalam kegiatan dakwah, justru kadang-kadang mendapatkan informasi "manggung" dari ustaz atau guru mengaji. Artinya, ulama yang menjadi panutan bagi ustaz dan guru mengaji tidak memonopoli informasi tentang kegiatan dakwah.

Berbagai kewenangan yang diberikan kepada kelompok muballig untuk menentukan jadwal kegiatan dakwah, materi ceramah, serta penempatan anggota muballig untuk tampil di suatu, menyebabkan keterampilan anggota untuk menentukan keputusan mutlak diperlukan. Kelompok muballig berdaulat dengan kekuasaan kebenaran dakwah sehingga diperlukan kedalaman intelektual dan kematangan emosional sehingga umat yang menjadi audiensnya tidak resah dengan informasi yang disampaikan dan tidak pula kecewa karena terjadinya ketertutupan kebenaran yang hendak diperoleh oleh jamaah.

Pola terintegrasi yang berbasis pada ideologi merujuk pada polarisasi organisasi besar di Indonesia yaitu Nahdlatul Ulama (NU) dan Muhammadiyah. NU menampilkan wajah kultural dengan slogan ablussunnah wal-jama'ah (pengikut tradisi mayoritas) yang sekarang dikonstruksi dengan sebutan dakwah yang menyejukkan. Muhammadiyah menampilkan wajah rasional dengan tekad pemberantasan TBC yang sekarang dikonstruksi dengan sebutan dakwah kritis.

216 Ilmu Dakwah: Academic Journal for Homiletic Studies, Vol. 10 No.2 | Juli-Des 2016 
Sehubungan dengan terpaan era globalisasi menyusul pula ideologi baru di kalangan muballig yaitu ideologi transnasional, seperti yang berlaku pada Hizbut Tahrir Indonesia (HTI), Partai Keadilan Sejahtera (PKS) dan Jamaah Tablig.

Para muballig yang bernaung dibawah NU selalu mendasarkan penyampaian materi dakwahnya berdasarkan kondisi lokal umat Islam yang menjadi audiensnya. Ideologi ablussunnah wa al-jamaah (pengikut tradisi dan mayoritas - biasa disingkat aswaja) menjadi patokan bagi muballig NU dalam rangka upaya membangun kekuatan tradisional umat Islam yang selama ini menjadi basis organisasi dengan julukan "bintang sembilan". Misi aswaja secara praktis selalu digambarkan oleh muballig NU dengan memperlihatkan amalanamalan agama yang dilakukan oleh para ulama yang dikenal oleh orang Makassar dengan sebutan anregurutta.

Demikian pula muballig Muhammadiyah dengan ideologi pembaruan dianggap sebagai "sepasang sandal" dengan NU dalam mengawal umat Islam Indonesia membangun peradaban dunia yang damai dan selalu mengedapankan dialog bilamana terjadi benturan peradaban (clash of civilisation). Muballig yang dikoordinir oleh Majelis Tablig Muhammadiyah, baik ditingkat pusat, wilayah dan daerah selalu berpegang teguh pada batang pokok ideologi dalam rangka mengantar umat Islam melaksanakan ajaran syariar dengan murni. Secara operasional, ideologi pembaruan selalu dijabarkan dengan langkah-langkah dakwah yang menjelaskan tentang pemberantasan penyakit keimanan yang beakronim TBC. TBC kepanjangan dari Takhyul, Bid'ah dan Churafat. Takhyul adalah akidah umat Islam yang selalu dicampur dengan aspek-aspek mistik seperti pohon yang keramat, batu yang bertuah, sungai yang berpenghuni dan lain-lain. Bid'ah adalah pelaksanaan ibadah yang bercampur dengan hal-hal yang tidak memiliki dasar hukum baik dari Al-Qur'an maupun dari Hadis. Sedangkan churafat (khurafat) adalah pelaksanaan ritual mistik yang terindikasi kepada permohonan keselamatan hidup selain kepada Allah SWT.

NU dan Muhammadiyah adalah organisasi massa yang dalam praktek keseharian, bukan hanya mengurus masalah ibadah atau ritual rutin lainnya tapi juga sudah memasuki wilayah ekonomi, budaya, sosial, pendidikan, poitik dan masalah-masalah kemasyarakatan lainnya. Dinamika dakwah yang juga mengikuti arus percaturan globalisasi, umat Islam Indonesia juga selalu mengadakan kontak dengan pelaksanaan dakwah internasional. Dampaknya, muncul tatanan baru tentang dakwah di Indonesia yang dikenal dengan ideologi transnasional.

Ideologi transnasional pernah dikemukakan oleh mantan Ketua Umum Pengurus Besar NU, KH. Hasyim Muzadi, dengan menunjuk organisasinya yaitu Ikhwanul Muslimin, Hizbut Tahrir dan Jamaah Tablig (Sabili, Edisi 25 Tahun XIV, 28 Juni 2007/13 Jumadil Akhir 1428). Ideologi ini terindikasi adanya hubungan kegiatan dakwah dengan negara lain. Kelompok-kelompok

Ilmu Dakwah: Academic Journal for Homiletic Studies, Vol. 10 No.2 | Juli-Des 2016217 
dakwah yang termasuk ideologi transnasional adalah Hizbut Tahrir dan Jamaah Tablig. Kedua oraganisasi itu berdiaspora secara struktural/organisasional di berbagai negara. Artinya pengikut ideologis Hizbut Tahrir dan Jamaah Tablig menjalankan kegiatannya sesuai dengan ketentuan hukum di mana negara mereka tinggal. Hizbut Tahrir selalu mengumandangkan tentang "komando tunggal" umat Islam dunia di bawah pemerintahan Daulah Islamiyah atau Khilafah. Sedangkan Jamaah Tablig dengan jelas menunjuk tiga negara yang menjadi tujuan khuruj yaitu India, Pakistan dan Bangladesh (IPB). Anggota Jamaah Tablig sangat mendambakan untuk mengunjugi ketiga negara itu sebagai "kesempurnaan" misi kerja dakwah.

Pola terintegrasi yang berbasis inspirasi ditunjukkan oleh muballig yang meniru tokoh-tokoh dakwah yang berhasil menyiarkan ajaran Islam. Nabi Muhammad SAW sebagai sumber inspirasi utama bagi muballig (uswatun hasanab), sehingga performa Nabi Muhammad dijadikan idola bagi para muballig.

Dengan demikian, pola komunikasi yang berbasis inspirasi di komunitas muballig di Kota Makassar terdiri atas inspirasi atas tokoh dakwah dan inspirasi untuk mendirikan lembaga dakwah karena melihat kesuksesan lembaga yang sudah ada. Pola inspirasi ini merupakan perjalanan muballig dalam mengasah keterampilan berdakwah sehingga muballig itu dapat menemukan identitasnya. Peran kelompok muballig menjadi sarana pembelajaran bagi anggota terhadap langkah-langkah seorang muballig yang ada peluang menjadi muballig terkenal. Sesama muballig akan memberi dukungan moril dan materil kepada sesama anggota seperti pendalaman keilmuan agama, kebahasaan, etika dan estetika.

\section{PENUTUP}

Pola komunikasi kelompok yang ditemukan pada komunitas muballig di Kota Makassar adalah komunikasi yang mengandung tata nilai kehidupan keagamaan, melalui simbol-simbol yang dipertukarkan pada setiap lapisan strata sosial. Tata nilai dan simbol itu telah diapresiasi oleh teori fenomenologi, teori tema-tema fantasi, teori strukturasi dan teori dramaturgi.

Realitas kehidupan muballig di Kota Makassar menampilkan simbolsimbol keagamaan yang menunjukkan adanya soliditas dan solidaritas kelompok. Kesan penampilan yang dibelajarkan menandai kekuatan komunikasi kelompok untuk mengantarkan muballig menjadi profesional dalam kehidupan sosial.

Pola komunikasi kelompok pada komunitas muballig di Kota Makassar adalah pola terintegrasi. Pola terintegrasi yang berbasis pada ideologi merujuk pada polarisasi organisasi massa, partai politik dan lembaga-lembaga dakwah di

218 Ilmu Dakwah: Academic Journal for Homiletic Studies, Vol. 10 No.2 | Juli-Des 2016 
Kota Makassar. Pola terintegrasi yang berbasis inspirasi ditunjukkan oleh muballig dengan meneladani, meniru dan mengidolakan muballig-muballig populer nan kharismatik, baik dari segi penampilan (estetika) maupun retorika. Sedangkan pola terintegrasi yang berbasis pada identitas, yakni para muballig di Kota Makassar bercirikan pada corak radikal, moderat dan liberal.

Sebagai saran untuk memperkaya khasanah pengetahuan dalam kajian komunikasi kelompok seyogyanya ada kajian lanjutan yang lebih luas dengan berbagai macam latar belakang, seperti suku, kegemaran, profesi, keagamaan dan lain-lain. Perlu selalu diadakan dialog antar pemimpin lembaga dakwah sehingga diperoleh informasi tentang peta dakwah yang komprehensif sebagai bahan kajian tentang dinamika keberadaan lembaga dakwah menuju terciptanya masyarakat yang adil dan makmur.

Untuk meciptakan harmonisasi antar komunitas, perlu dibentuk konsorsium yang melibatkan pemimpin-pemimpin komunitas untuk mengadakan peningkatan keterampilan para anggotanya, yang meliputi keterampilan fisik dan keterampilan non fisik seperti pelatihan manajemen pengendalian emosi sehingga tawuran antar kelompok dapat diredam.

\section{DAFTAR PUSTAKA}

Ahmad, Abd. Kadir. 2008. Ulama Bugis. Makassar : Indobis Publishing.

Arief, Aburaerah dan Hakim, Zainuddin (editor). 1993. Sinrilikna Kappalak Tallumbatua. Jakarta : Yayasan Obor Indonesia.

As'ad, Muhammad. 2009. "Pondok Pesantren As'adiyah". Jurnal Al-Qalam, Volume 15 Nomor 24, Juli-Desember 2009. Makassar : Balai Litbang Agama.

Azra, Azyumardi, 2005. Jaringan Ulama Timur Tengah dan Kepulauan Nusantara Abad XVII \& XVIII. Jakarta : Prenada Media.

Azra, Azyumardi, 2009. "Kiprah Ulama Indonesia Menembus Hegemoni Mekkah" dalam Subhan SD (wartawan), Kompas, 17 Desember 2009.

Damanik, Abdul Hadi MA. 2004. "Amuntai Saksi Bisu Pengkhianatan Bung Karno". Majalah Suara Hidayatullah. Surabaya : Yayasan Penerbitan Pers Hidayatullah.

Djaelani, H.A. Kadir. 1997. Konsepsi Pendidikan Agama Islam dalam Era Transformasi Global. Jakarta : CV. Putra Harapan.

Hamid, Abu. 2005. Syekh Yusuf Seorang Ulama, Sufi dan Pejuang. Jakarta : Yayasan Obor Indonesia.

Hasrun, Muhammad dan Khadijah, St. 2007. "AGH. Abdul Muin Yusuf; Ulama Pejuang dari Sidenreng", dalam Ruslan, Muhammad (editor). 2007. Ulama Sulawesi Selatan; Biografi Pendidikan \& Dakwah. Makassar : Majelis Ulama Indonesia Propinsi Sulawesi Selatan.

Ilmu Dakwah: Academic Journal for Homiletic Studies, Vol. 10 No.2 | Juli-Des 2016219 
Karim. M. Ruslim. 1995. "Konflik Islam Kontemporer di Indonesia”. Jurnal Prisma, No. 5 Tahun 1995.

Khaldun, Ibn. Tarikh Ibn Khaldun, Juz 1 . 1992. Beirut : Maktabah al-Lubnan.

Matrisasi, Fitrisia. 2010. "Sejarah; dari Makassar ke Macassar". Kompas, 17 Juni 2010.

Mattulada. 1995. Latoa Satu Lukisan Antropologi Politik Orang Bugis. Makassar : Hasanuddin University Press.

Mattulada. 1991. Menyusuri Jejak Kehadiran Makassar Dalam Sejarah. Makassar : Hasanuddin University Press.

Mulyana, Deddy. 2010. Komunikasi Lintas Budaya; Pemikiran, Perjalanan dan Khayalan. Bandung : PT Remaja Rosdakarya.

Muzakkar, Abd. Aziz Kahar. 2007. "Masa Transisi dari Stigma ke Penerimaan", dalam Ahmad, H. Abd. Kadir, 2007. Potret KPPSI dari Perspektif Tokoh. Makassar: Balai Penelitian dan Pengembangan (Litbang) Agama.

Nur, Azhar. 2007. "AGH. Muhammad Yunus Martan; Pengarang dari Sengkang", dalam Ruslan, Muhammad (editor). 2007. Ulama Sulawesi Selatan; Biografi Pendidikan \& Dakwah. Makassar : Majelis Ulama Indonesia Propinsi Sulawesi Selatan.

Omar, Toha Jahja. 1971. Imu Da'wah. Djakarta : Widjaja.

Ondeng, Syarifuddin. 2007. "AGH. Abdurrahman Ambo Dalle; Pendiri Darud Dakwah wal-Irsyad", dalam Ruslan, Muhammad (editor). 2007. Ulama Sulawesi Selatan; Biografi Pendidikan \& Dakwah. Makassar: Majelis Ulama Indonesia Propinsi Sulawesi Selatan.

Patunru, Abd. Razak Daeng. 1969. Sedjarah Gowa. Makassar : Yayasan Kebudayaan Sulawesi Selatan dan Tenggara.

Pettalongi, Noor Sulaiman. 2001. Islam di Tanah Kaili; dari Datokarama ke Guru Tua. Palu : STAIN Datokarama Palu.

Shambazy, Budiarto. 2010. "45 Tahun "Kudeta Merangkak"”. Kompas, 25 September 2010.

Sewang, Ahmad M. 2005. Islamisasi Kerajaan Gowa Abad XVI sampai Abad XVII. Jakarta : Yayasan Obor Indonsia.

Soeroto, Myrtha. 2003. Dari Arsiktektur Tradisional Menuju Arsitektur Indonesia. Jakarta : Ghalia Indonesia.

Supriyadi, Dedi. 2008. Sejarah Peradaban Islam. Bandung : Pustaka Setia.

Susdiyanto. 2007. "AGH. Daud Ismail; Ulama Kharismatik dari Soppeng", dalam Ruslan, Muhammad (editor). 2007. Ulama Sulawesi Selatan; Biografi Pendidikan \& Dakwah. Makassar : Majelis Ulama Indonesia Propinsi Sulawesi Selatan.

Tim Penterjemah Departemen Agama. 2005. Al-Qur'an dan Terjemahnya. Bandung : PT Syaamil Cipta Media.

Tim Penyusun Departemen Pendidikan dan Kebudayaan. 1995. Kamus Besar Bahasa Indonesia. Jakarta : Balai Pustaka.

Tim Penyusun Departemen Pendidikan dan Kebudayaan. 1997. Sejarah Daerah Sulawesi Tengah. Palu : Departemen Pendidikan dan Kebudayaan.

220 Ilmu Dakwah: Academic Journal for Homiletic Studies, Vol. 10 No.2 | Juli-Des 2016 
Tudjimah. 1997. Syekh Yusuf Makasar Riwayat dan Ajarannya. Jakarta : Universitas Indonesia (UI-Press).

Turmudi, Endang. 2004. Perselingkuban Kiai dan Kekuasaan. Yogyakarta : LKiS.

IImu Dakwah: Academic Journal for Homiletic Studies, Vol. 10 No.2 | Juli-Des 2016221 